\title{
In Memory of Erin K. Espeland
}

\author{
Myla FJ. Aronson
}

$\mathrm{O}$ ne year ago, we lost an important member of our community. Erin K. Espeland was an editorial board member of Ecological Restoration for four years, and greatly influenced the scientific rigor and impact of Ecological Restoration. She was a devoted editor, and took her duties seriously, for the benefit of both the journal and the authors. On every article she handled, she strove to help the authors craft their manuscripts into top-quality research communications. Her careful reviews were detailed and greatly improved every manuscript.

Erin was an important scientist in native plant restoration, particularly in the Great Plains and California grasslands. For the last 10 years, Erin was a Research Ecologist at the USDA Agricultural Research Service. Her work focused on native plant conservation and restoration, including invasive plant management and evolutionary ecology of invasive non-native and native plants. Her most recent work focused on understanding the consequences of plant choice for restoration: local adaptation, competition, plasticity in native plants, and the potential for plant choice to alleviate climate change impacts. Her work, spanning over 70 peer-reviewed journal articles, book chapters, and reports, has been cited over 1,000 times and will continue to impact restoration research and practice for decades to come.

Erin earned her BA in Music at Mills College, CA. She then moved to ecology, earning an MS in Biology at San Jose State University and a PhD at University of California, Davis. She was a mentor to young scientists devoting her time, intellect, and enthusiasm to the next generation of ecologists and restorationists. Erin was also a musician, writing and performing her own songs, inspired by the people and landscapes of the places she lived, particularly California, Montana, and Nevada.

Although I never met Erin in person, I liked and respected her immensely. We often exchanged emails, and she struck me as an incredibly driven and energetic scientist who cared deeply about others as well as her work and the applied aspects for restoration success. Her work has influenced my own and I strive to reach her optimism in this, the Anthropocene era.

Erin's memory is being honored by the California Native Plant Society, which has established the Erin Espeland Internship for students studying native plants. For more information and to donate to the Internship, see www.cnps. org/education/students/erin-espeland-internship.

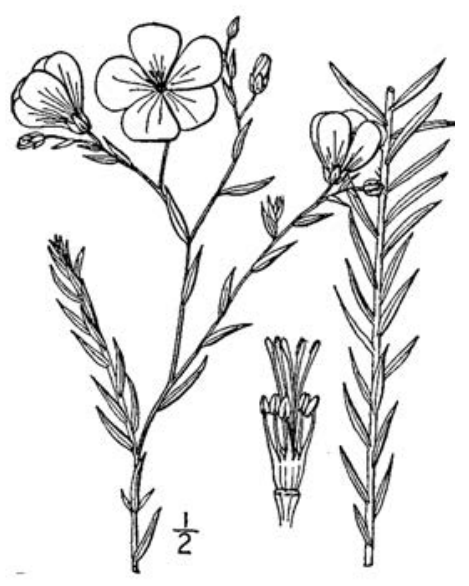

Linum lewisii. USDA-NRCS PLANTS Database. Britton, N.L. and A. Brown. 1913. An Illustrated Flora of the Northern United States, Canada and the British Possessions. New York, NY: Charles Scribner's Sons.

Ecological Restoration Vol. 37, No. 3, 2019

ISSN 1522-4740 E-ISSN 1543-4079

(C2019 by the Board of Regents of the University of Wisconsin System. 